九州大学学術情報リポジトリ

Kyushu University Institutional Repository

Response of Growth, Gas Exchange and PSII

Electron Transport in Greengram (Vigna radiata

L., Wi lczek) Varieties and Other Pulse Species

to Drough and Re-watering

Oo, Htay Htay

Graduate School of Bioresource and Bioenvironmental Sciences, Kyushu University

Araki, Takuya

Department of Plant Resources Faculty of Agriculture Kyushu University

Saito, Kazuyuki

Department of Plant Resources Faculty of Agriculture Kyushu University

Kubota, Fumitake

Department of Plant Resources Faculty of Agriculture Kyushu University

https://doi.org/10.5109/10064

出版情報：九州大学大学院農学研究院紀要. 53 (1)，pp.19-25，2008-02-28. Faculty of Agriculture， Kyushu University

バージョン :

権利関係 : 


\title{
Response of Growth, Gas Exchange and PSII Electron Transport in Greengram (Vigna radiata L., Wilczek) Varieties and Other Pulse Species to Drought and Re-watering
}

\author{
Htay Htay OO ${ }^{1}$, Takuya ARAKI*, Kazuyuki SAITOU \\ and Fumitake KUBOTA
}

\author{
Laboratory of Plant Production Physiology, Division of Soil Science and Plant Production, \\ Department of Plant Resources, Faculty of Agriculture, Kyushu University, \\ Fukuoka 812-8581, Japan \\ (Received October17, 2007 and accepted November 30, 2007)
}

\begin{abstract}
Drought resistance and recovery of greengram (Vigna radiata L. Wilczek) varieties (vars.), Kanti, Yezin-4, VC1973A and V3726, improved varieties in Myanmar, were compared in pot experiments based on the parameters related to growth and photosynthesis. At the vegetative stage (30th day after planting), the plants were subjected to four-day drought treatment during which the water supply was reduced to $20 \%$ of the control. At the end of the drought treatment, the plants were re-watered for three days as a recovery treatment. A significant varietal difference was observed in growth parameters, $\mathrm{CO}_{2}$ exchange rate (CER), stomatal conductance $\left(\mathrm{G}_{\mathrm{s}}\right)$, PSI electron transport (ETR) and non-photochemical quenching (NPQ) at the end of drought and re-watering treatments. Of the four varieties, vars. Kanti and Yezin-4 sustained a comparatively large value of $\mathrm{G}_{\mathrm{s}}$ because of their relatively higher sustainability of CER and ETR and having lesser NPQ under drought condition. This result suggests that the $\mathrm{CO}_{2}$ assimilation and PSI function in both varieties were less affected by drought, and could continue photosynthetic energy flow. Moreover, both vars. Kanti and Yezin-4 showed a better recovery in growth, gas exchange and PSI function at the rewatering treatment. There was the evidence that greengram (var. Kanti) had a high drought-resistance and quick recovery, compared with blackgram (Vigna mungo L. Hepper, var. P-11-30) and soybean (Glycine max L., var. Asoaogari).
\end{abstract}

\section{INTRODUCTION}

The pulse crops are widely grown as a second crop in the rice-based cropping system in Myanmar. Greengram has been produced as one of the important export crop items recently and thus, the cultivated area is rapidly increasing today. However, the current grain yield of greengram in Myanmar remains around $800 \mathrm{~kg}$ $\mathrm{ha}^{-1}$, which is considerably below the reported yield potential of around $3000 \mathrm{~kg} \mathrm{ha}^{-1}$. The adverse climatic environment, such as drought, is one of the main causes for a low and unstable yield of greengram especially in the dry regions of Myanmar.

The occurrence of morphological and physiological responses, which may lead to some adaptation to drought stress, may vary considerably among the species. Stomatal regulation of photosynthesis during drought have been well documented (Chaves, 1991) and it played the dominant role in controlling the decline of net $\mathrm{CO}_{2}$ uptake, by leading to decrease in leaf internal $\mathrm{CO}_{2}$ concentrations (Cornic, 2000). The effect of drought stress and recovery on leaf gas exchange and fluorescence parameters has been extensively studied with a number of species including soybean, cowpea and kidney bean by Earl (2002), Souza et al. (2004) and Miyashita et al. (2005), respectivety. However, only a little information for greengram is provided on the gen-

${ }^{1}$ Laboratory Plant Production Physiology, Division of Soil Science and Plant Production, Graduate School of Bioresource and Bioenvironmental Sciences, Kyushu University

* Corresponding author (E-mail: araki@agr.kyushu-u.ac.jp) otypic and specific variation of $\mathrm{CO}_{2}$ assimilation and photosystem II (PSII) functions in response to drought.

Recently, high yielding improved greengram varieties have been released and grown with dramatic area expansion in Myanmar. The aim of this study was to evaluate the responses of photosynthesis to drought in greengram varieties in terms of growth, $\mathrm{CO}_{2}$ exchange rate and PSII electron transport situation. Also the response of greengram was compared with that of other pulses such as blackgram and soybean. By identifying the varietal and specific features in drought response or resistance, it is possible to obtain the fundamental information on further improvement of photosynthetic production and yield stability of greengram varieties under drought condition.

\section{MATERIALS AND METHODS}

The study was conducted through two experiments (i) the varietal difference in drought resistance was investigated on greengram (Vigna radiata L. Wilczek) and (ii) the specific difference was studied between greengram and other pulses such as blackgram (Vigna mungo L. Hepper) and soybean (Glycine max L.).

\section{Materials used and treatments in Experiment 1 and 2 Experiment 1 \\ Four promising greengram varieties: Kanti, Yezin-4, VC1973A and V3726, recently released in Myanmar were used. The experiment was carried out in the experimental field of Kyushu University (33 $35^{\circ}$}


N, $130^{\circ} 23^{\prime}$ E) during June to July 2005. Five gram of compound chemical fertilizer (N: $\mathrm{P}: \mathrm{K}=16: 16: 16)$ was added into the 8-litter pot of sandy loam soil. Pregerminated seeds of the four varieties were planted together in each pot. After germination, plants were thinned to four plants (one plant for each variety) in a pot, and grown for 30 days under the outdoor condition. During which all the pots were irrigated everyday to maintain the sufficient soil water status. The treatments, which consisted of two steps, were imposed on 30-day old plants: (1) four-day drought treatment and (2) three-day recovery treatment by re-watering. During the drought treatment, water supply was reduced to $20 \%$ of the control, by which the soil water potential (SWP) in pots decreased to $-2.26 \mathrm{MPa}$ on average. At the end of the drought treatment, the plants were re-watered to observe the photosynthetic recovery.

Experiment 2

The second experiment was conducted during July to August following the experiment 1. Materials used here were three pulse species: greengram (var. Kanti), blackgram (var. P-11-30) and soybean (var. Asoaogari). var. Kanti is a variety with the highest resistibility to drought among the four varieties tested in the experiment 1. var. P-11-30 is widely grown in the dry area in Myanmar, and var. Asoaogari is grown in the southern area in Japan. The experimental site and treatment procedures were the same as those of the experiment 1 . These three species were grown together in a pot. By the drought treatment, soil water potential was decreased to $-2.15 \mathrm{MPa}$ on average.

\section{Growth parameters}

Growth parameters such as leaf area, shoot dry weight (SDW) and root dry weight (RDW) of a plant were measured before and after the end of drought treatment. Six plants were sampled for each cultivar in each treatment. Dry weight was determined after fiveday oven drying at $80^{\circ} \mathrm{C}$. The leaf area (LA) per plant was measured with an automatic area meter (AAM-8, Hayashi-denko, Japan). Plant growth rate (PGR) was calculated by the equation (1).

$$
\mathrm{PGR}=\left(\mathrm{W}_{2}-\mathrm{W}_{1}\right) /\left(\mathrm{t}_{2}-\mathrm{t}_{1}\right)
$$

where $\mathrm{W}_{1}$ and $\mathrm{W}_{2}$ are dry weight of plants determined at the harvesting days of $t_{1}$ and $t_{2}$, respectively.

\section{Soil and leaf water potentials}

The water potentials of soil and leaf were determined with a dew-point meter (WP 4 , Decagon Devices, USA). The parameter values were read between 8:00 and 10:00 am. The soil samples for soil water potential (SWP) measurement were taken from three points in the root growing zone in a pot. For leaf water potential (LWP) measurement, leaf disks were excised from active expanded leaves.

Gas exchange rate and chlorophyll fluorescence emission measurements
The $\mathrm{CO}_{2}$ concentration and vapor pressure in the reference and sample air were monitored with an infrared $\mathrm{CO}_{2}$ analyzer (Li-6262, LI-COR, USA). Measurements were performed using active expanded leaves at the 4th day after drought treatment began and at the 3rd day in re-watering treatment under the conditions of $380 \pm 10 \mu \mathrm{L} \mathrm{L}^{-1}$ in $\mathrm{CO}_{2}$ concentration, $30 \pm 1{ }^{\circ} \mathrm{C}$ in leaf temperature, $60 \%$ in relative humidity, and $600 \mu \mathrm{mol} \mathrm{m} \mathrm{m}^{-2} \mathrm{~s}^{-1}$ in photosynthetic photon flux density (PPFD). The leaf area enclosed in the assimilation chamber was $0.000625 \mathrm{~m}^{2}$, and the airflow rate was $0.706 \mathrm{mmols}^{-1}$. Based on the measured values, the parameters of $\mathrm{CO}_{2}$ exchange rate (CER) and stomatal conductance $\left(\mathrm{G}_{\mathrm{s}}\right)$ were calculated according to the method described by Long and Hallgren (1985).

Together with the gas exchange rate of a leaf, the chlorophyll fluorescence of the photosystem II (PSII) was monitored with a fluorescence probe (PAM-2000, Walz, Germany) equipped on the assimilation chamber. The initial fluorescence $\left(\mathrm{F}_{\mathrm{o}}\right.$ ) was measured using a 20-minute dark-adapted leaf under a measuring beam (3.2 $\left.\mu \mathrm{mol} \mathrm{m} \mathrm{m}^{-2} \mathrm{~s}^{-1} \mathrm{PPFD}\right)$, and then the maximum chlorophyll fluorescence $\left(\mathrm{F}_{\mathrm{m}}\right)$ was determined by giving a $0.8 \mathrm{~s}$ saturating pulse (8000 $\mu \mathrm{mol} \mathrm{m} \mathrm{m}^{-2} \mathrm{~s}^{-1}$ PPFD) to this leaf. Then, the time course of the fluorescence quenching $\left(\mathrm{F}_{\mathrm{s}}\right)$ was monitored at $600 \mu \mathrm{mol} \mathrm{m}{ }^{-2} \mathrm{~s}^{-1}$ PPFD, during which the fluorescence spike $\left(\mathrm{F}_{\mathrm{m}}{ }^{\prime}\right)$ was periodically measured by giving pulses of saturating light.

The equations (2) to (5) were adopted to calculate the following parameters: the maximum quantum yield $\left(\mathrm{F}_{\mathrm{v}} / \mathrm{F}_{\mathrm{m}}\right)$ was calculated from the equation by van Kooten and Snel (1990), the quantum yield of PSI $\left(\Phi_{\mathrm{e}}\right)$ by Genty et al. (1989), the apparent rate of electron transport through PSII (ETR) by Krall and Edwards (1992) and the coefficient of non-photochemical quenching of excitation energy (NPQ) by Bilger and Björkman (1990)

$$
\begin{aligned}
& \mathrm{F}_{\mathrm{v}} / \mathrm{F}_{\mathrm{m}}=\left(\mathrm{F}_{\mathrm{m}}-\mathrm{F}_{\mathrm{o}}\right) / \mathrm{F}_{\mathrm{m}} \\
& \Phi_{\mathrm{e}}=\left(\mathrm{F}_{\mathrm{m}}{ }^{\prime}-\mathrm{F}_{\mathrm{s}}\right) / \mathrm{F}_{\mathrm{m}}, \\
& \mathrm{ETR}=\Phi_{\mathrm{e}} I \mathrm{ab} \\
& \mathrm{NPQ}=\left(\mathrm{F}_{\mathrm{m}}-\mathrm{F}_{\mathrm{m}}{ }^{\prime}\right) / \mathrm{F}_{\mathrm{m}},
\end{aligned}
$$

where $I$ is the PPFD supplied to a leaf; a=0.5, the fraction of absorbed quanta that used by PSII (assuming the supplied photons are equally distributed between photosystems I and II), and $b=0.84$, which is an average of light absorption coefficient in C3 plant leaves (Schultz, 1996). The measurements of gas exchange and chlorophyll fluorescence were carried out on the same leaf with four replications.

\section{RESULTS AND DISCUSSION}

\section{Varietal difference in drought resistance and recovery of greengram varieties}

Fig. 1 shows the effects of re-watering treatment on SDW, RDW, LA and PGR in the four varieties of greengram. In the control pots, no or little varietal difference was found in SDW, LA and PGR except RDW 

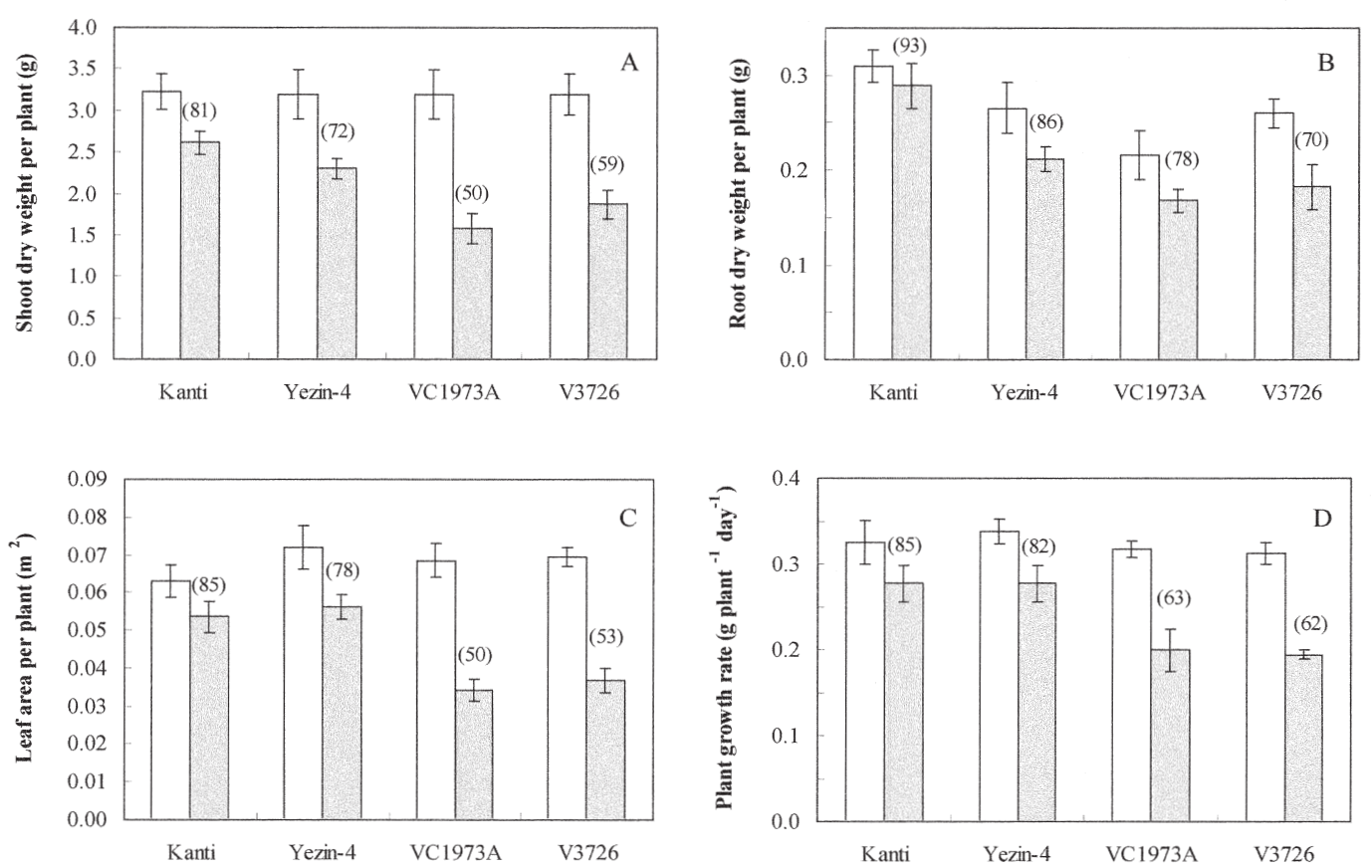

Fig. 1. Shoot dry weight (A), root dry weight (B), leaf area (C) and plant growth rate (D) of four greengram varieties in control $(\square)$ and recovery $(\square)$. Data represent mean \pm SE of six replications. Number in the parentheses represents the percentage of recovery to the control value.

which showed the largest value in var. Kanti. On the other hand, there was a large varietal difference in the response of these four parameters to the re-watering treatment: a large reduction was found in all parameters of vars. VC1973A and V3726, while a less reduction in vars. Kanti and Yezin-4. For example, the decline in LA was $47 \%$ in var. V3726, and $15 \%$ in var. Kanti, and that of PGR in those varieties were 38 and $15 \%$, respectively. During the drought treatment, SWP was finally decreased to $-2.26 \mathrm{MPa}$ by the restriction of water supply. The effects of drought on plants would be changed depending on its treatment period and severity, but the SWP level and treatment period of four days used here are considered to be adequate for drought resistant test of greengram varieties.

Leaf area has been frequently reported to have a close relationship with crop growth production. The decrease in LA by the drought treatment was closely related with that in PGR (Fig. 1-C and D). This means that vars. Kanti and Yezin-4 having a better sustainability in LA kept a high PGR under the recovery condition. These growth responses may suggest that vars. Kanti and Yezin-4 have a strong drought resistance in their biomass production system. Anyia and Herzog (2004) stated that photosynthetic rates of water stress cowpea plants were higher than unstressed plants after drought released and resulted a higher in dry matter accumulated in some genotypes.

The water uptake was limited by the amount of roots, and the enhancement of root growth could increase droughtresistance according to Klepper and
Rickman (1990) and many other researchers. Plant productivity under drought stresses is closely related to the processes of dry matter partitioning and the spatial and temporal root distribution (Kage et al., 2004). In our study, as shown in Fig. 1-B, a large value of RDW was shown in Kanti, which might be related to drought resistance.

Table 1 showed CER, $\mathrm{G}_{\mathrm{s}}, \mathrm{Fv} / \mathrm{Fm}$, ETR and NPQ in the four varieties observed under the drought and rewatering conditions. There was no significant difference in CER under the control condition. However, under the drought condition CER of vars. Kanti and Yezin-4 sustained relatively high and the recovery of these cultivars were superior to the other two varieties, vars. VC1973A and V3726. The depressions in CER of vars. Kanti and Yezin-4 were 27 and 25\% under the drought condition, respectively, while those of vars. VC1973A and V3726 were 49 and 39\%, respectively. These facts mean that vars. Kanti and Yezin-4 may have higher droughtresistance in photosynthesis, and also higher recovery potential. Anyia and Herzog (2004) reported that photosynthetic rate declined almost linearly as water deficit increased. However, compensatory growth was evidenced in the recovery stage as determined by gas exchange measurement.

For the response of $\mathrm{G}_{\mathrm{s}}$, there was no significant difference under the control but distinguishable varietal difference was observed in both drought and re-watering treatments. A large value of $\mathrm{G}_{\mathrm{s}}$ was shown in vars. Kanti and Yezin-4 under these conditions. This response represented a similar trend to that of CER in 
Table 1. $\mathrm{CO}_{2}$ exchange rate and photosystem II parameter values in four greengram varities observed under the drought and re-watering conditions

\begin{tabular}{|c|c|c|c|c|c|c|c|c|c|c|c|c|c|c|c|}
\hline \multirow[t]{2}{*}{ Vatiety } & \multicolumn{2}{|c|}{$\begin{array}{c}\text { CER } \\
\left(\mu \mathrm{mol} \mathrm{m}^{-2} \mathrm{~s}^{-1}\right)\end{array}$} & \multicolumn{3}{|c|}{$\begin{array}{c}\mathrm{G}_{\mathrm{s}} \\
\left(\mathrm{mol} \mathrm{m} \mathrm{s}^{-1} \mathrm{~s}^{-1}\right)\end{array}$} & \multicolumn{3}{|c|}{$\mathrm{F}_{\mathrm{v}} / \mathrm{F}_{\mathrm{m}}$} & \multicolumn{3}{|c|}{$\begin{array}{c}\text { ETR } \\
\left(\mu \mathrm{mol} \mathrm{m}^{-2} \mathrm{~s}^{-1}\right)\end{array}$} & \multicolumn{3}{|c|}{$\mathrm{NPQ}$} & \\
\hline & Control & Drought & & Control & Drought & & Control & Drought & & Control & Drought & & Control & Drought & \\
\hline Kanti & $13.44 \mathrm{a}$ & $9.81 \mathrm{a}$ & (73) & $0.165 \mathrm{a}$ & $0.118 \mathrm{a}$ & (71) & $0.834 \mathrm{a}$ & $0.832 \mathrm{a}$ & (100) & $161.4 \mathrm{a}$ & $145.0 \mathrm{a}$ & (96) & $0.507 \mathrm{a}$ & $0.653 \mathrm{a}$ & (129) \\
\hline Yezin-4 & $12.63 \mathrm{a}$ & $9.47 \mathrm{a}$ & (75) & $0.163 \mathrm{a}$ & $0.121 \mathrm{a}$ & (74) & 0.819 a & $0.812 \mathrm{a}$ & (99) & $140.6 \mathrm{a}$ & $138.1 \mathrm{a}$ & (98) & $0.453 \mathrm{a}$ & $0.583 \mathrm{a}$ & (129) \\
\hline VC1973A & $13.44 \mathrm{a}$ & $6.81 \mathrm{~b}$ & (51) & $0.159 \mathrm{a}$ & $0.077 \mathrm{a}$ & (48) & $0.826 \mathrm{a}$ & $0.809 \mathrm{a}$ & (99) & $140.2 \mathrm{a}$ & $114.2 \mathrm{ab}$ & (81) & $0.388 \mathrm{a}$ & $0.712 \mathrm{a}$ & (183) \\
\hline V3726 & $12.88 \mathrm{a}$ & $7.87 \mathrm{ab}$ & (61) & $0.157 \mathrm{a}$ & $0.091 \mathrm{a}$ & (58) & $0.825 \mathrm{a}$ & $0.814 \mathrm{a}$ & (99) & $138.5 \mathrm{a}$ & $108.5 \mathrm{~b}$ & (78) & $0.351 \mathrm{a}$ & $0.693 \mathrm{a}$ & (197) \\
\hline \multirow[t]{2}{*}{ Average } & 13.10 & 8.49 & (65) & 0.161 & 0.102 & (63) & 0.829 & 0.817 & (99) & 145.2 & 126.5 & (88) & 0.613 & 0.983 & (159) \\
\hline & Control & Re-water & & Control & Re-water & & Control & Re-water & & Control & Re-water & & Control & Re-water & \\
\hline Kanti & $14.02 \mathrm{a}$ & $13.96 \mathrm{a}$ & (100) & $0.168 \mathrm{a}$ & $0.163 \mathrm{a}$ & (97) & $0.84 \mathrm{a}$ & $0.84 \mathrm{a}$ & (100) & $134.9 \mathrm{a}$ & $149.6 \mathrm{a}$ & (111) & $0.670 \mathrm{a}$ & $0.665 \mathrm{a}$ & (99) \\
\hline Yezin-4 & $13.23 \mathrm{a}$ & $12.53 \mathrm{a}$ & (95) & $0.161 \mathrm{a}$ & $0.155 \mathrm{a}$ & $(96)$ & $0.820 \mathrm{a}$ & $0.824 \mathrm{a}$ & $(100)$ & $142.3 \mathrm{a}$ & $141.8 \mathrm{a}$ & (100) & 0.598 a & $0.652 \mathrm{a}$ & (115) \\
\hline VC1973A & $13.02 \mathrm{a}$ & $10.81 \mathrm{~b}$ & (83) & $0.158 \mathrm{a}$ & $0.115 \mathrm{~b}$ & (73) & 0.822 a & $0.819 \mathrm{a}$ & (99) & $132.3 \mathrm{a}$ & $116.2 \mathrm{ab}$ & (88) & $0.596 \mathrm{a}$ & $0.698 \mathrm{a}$ & (117) \\
\hline V3726 & $14.21 \mathrm{a}$ & $10.04 \mathrm{~b}$ & (72) & $0.161 \mathrm{a}$ & $0.114 \mathrm{~b}$ & (71) & 0.832 a & $0.821 \mathrm{a}$ & (99) & $121.4 \mathrm{~b}$ & $100.8 \mathrm{~b}$ & (83) & $0.504 \mathrm{a}$ & $0.572 \mathrm{a}$ & (113) \\
\hline Average & 13.62 & 11.84 & (88) & 0.164 & 0.142 & (84) & 0.829 & 0.825 & (100) & 132.7 & 127.1 & (96) & 0.592 & 0.827 & (111) \\
\hline
\end{tabular}

CER, $\mathrm{CO}_{2}$ exchange rate; $\mathrm{G}_{\mathrm{s}}$, stomatal conductance; ETR, electron transport rate; $\mathrm{F}_{\mathrm{v}} / \mathrm{F}_{\mathrm{m}}$, PSII maximum quantum yield; NPQ, nonphotochemical quenching. In a column for each treatment group, mean values followed by the same letters are not significantly different at $5 \%$ level by Duncan's test. Number in the parentheses indicates the percent of the drought to the control value.

both varieties, showing the close relationship between $\mathrm{G}_{\mathrm{s}}$ and CER. This may mean that varieties having a higher $\mathrm{G}_{\mathrm{s}}$ under the drought condition are able to keep an efficient photosynthetic production.

Of the four varieties, vars. Kanti and Yezin-4 were able to keep almost constant levels of CER and $\mathrm{G}_{\mathrm{s}}$ : the reduction was only by $25-27 \%$ in CER and $26-29 \%$ in $\mathrm{G}_{\mathrm{s}}$ under the drought. On the other hand, the reduction in vars. V3726 and VC1973A was 39-49\% in CER and $42-52 \%$ in $\mathrm{G}_{\mathrm{s}}$. The values of $\mathrm{G}_{\mathrm{s}}$ in vars. Kanti and Yezin-4 were almost completely returned up to the control levels at the 3rd day after re-watering, but those were not found in vars. V3726 and VC1973A. The decrease in CER in greengram varieties is in parallel with the decrease in $\mathrm{G}_{\mathrm{s}}$, and thus $\mathrm{G}_{\mathrm{s}}$ is one of the important determinants for CER.

Next, the parameters related to PSII electron transport in a leaf were examined. As shown in Table1, there was no significant difference in $\mathrm{F}_{\mathrm{v}} / \mathrm{F}_{\mathrm{m}}$ between varieties, and no affect by drought and re-watering treatments. Genty et al. (1987) and Souza (2004) stated that a slight change in $\mathrm{F}_{\mathrm{v}} / \mathrm{F}_{\mathrm{m}}$ was observed in plants experienced severe drought. Similarly, in our experiment $\mathrm{F}_{\mathrm{v}} /$ $\mathrm{F}_{\mathrm{m}}$ ratios, examined in greengram varieties were less affected by the treatments as compared to other PSI parameters. This may suggest that the light catching apparatus in PSII was not severely damaged by the drought stress imposed here.

A leaf with a high ETR is regarded as keeping an efficient energetic flow from the chemical energy production site of PSII to $\mathrm{CO}_{2}$ assimilation site. ETR values in vars. Kanti and Yezin-4 were not affected by the drought treatment, while those in vars. VC1973A and V3726 were decreased by 19 and 22\%, respectively (Table 1). In vars. Kanti and Yezin-4, their CER and $\mathrm{G}_{\mathrm{s}}$ were, as mentioned, decreased by the drought treatment, but ETR did not decline. The photorespiration rate is known to increase in a leaf having a low $\mathrm{G}_{\mathrm{s}}$ value, because the intercellular $\mathrm{CO}_{2}$ concentration decreased by the restriction of gas exchange. The increase in photorespiration causes the decrease in CER and increases ETR because photorespiration is the metabolism with high energy consumption (Cornic, 2000). It is considered that a smooth flow of electron flow observed in vars. Kanti and Yezin-4 is effective in preventing a physiological inhibition caused by the excessive accumulation of photon energy supplied from the photosystem during the drought. Therefore, in vars. Kanti and Yezin-4, the photosynthetic apparatus was less damaged during drought period, and their CER, Gs and ETR recovered quickly after re-watering, while not in vars. VC1973A and V3726.

NPQ is a parameter indicating the efficiency of heat dissipation in PSII. The increase in NPQ occurs when the $\mathrm{CO}_{2}$ assimilation is restricted in a leaf during the period of drought, by which the excessive energetic excitation can be effectively dissipated. The value of NPQ was different between varieties, and a higher value was observed in vars. V3726 and VC1973A (183$197 \%)$ than in vars. Kanti and Yezin-4 (129\%) under the drought treatment (Table 1). This may suggest that the energy excessively produced in a leaf of these varieties was dissipated more as heat without being used for $\mathrm{CO}_{2}$ assimilation during drought stress. Maxwell and Jonhson (2000) reported that great values of non-photochemical quenching in cowpea were observed around maximum stress and they may have resulted from the occurrence of both photoprotective and photodamaging mechanisms. This phenomenon was also found in this experiment.

As mentioned above, of the four varieties of greengram, vars. Kanti and Yezin-4 are regarded as varieties having a high droughtresistance and better recovery, from the viewpoints of the response of $\mathrm{CO}_{2}$ assimilation and PSII functions. The important determinant of enhancing droughtresistance is the sustainability of high $\mathrm{G}_{\mathrm{s}}$ value in leaves under drought conditions. In this situation, the gas exchange of leaves is not greatly 
restricted, by which CER and ETR are able to keep relatively high levels; thereby, excessive energy is not accumulated in a photosynthetic apparatus in a leaf. Therefore, heat dissipation does not occur so much in the leaf and NPQ is not increased.

A rapid increase in the assimilation rates of waterstressed plants upon re-watering indicates that the basic mechanism of photosynthetic biochemistry and photochemistry is not impaired by the lack of water, leading to the conclusion that decreases in net $\mathrm{CO}_{2}$ uptake are result of stomata closure (Cornic, 2000). It was proved that CER and $\mathrm{G}_{\mathrm{s}}$ of vars. Kanti and Yezin-4 were able to have a quick recovery by re-watering. The varieties having a mild-sensitivity in $\mathrm{G}_{\mathrm{s}}$ or lenient stomatal-response to water environments are suggested to have superiority in stress-resistant or growth stability. From the viewpoint of water economics, a high $\mathrm{G}_{\mathrm{s}}$ is not beneficial under drought conditions, but the depression of $\mathrm{G}_{\mathrm{s}}$ by complete stomatal closure shows the adverse effect on energy balance between photosynthetic apparatuses. Although further investigations are required under field conditions for this trait, the introduction of such greengram varieties as Kanti and Yezin-4 is expected to improve greengram production in the dry regions of Myanmar. A large genotypic variation shown in greengram used here may suggest that there is a high possibility to improve stress-resistant variety.

\section{Drought resistance of greengram in comparison with black gram and soybean}

In the experiment 1 , var. Kanti had a higher resistance to drought among the four greengram varieties. Blackgram and soybean are also the important pulse crops widely grown in Myanmar; particularly, a variety $\mathrm{P}-11-30$ of blackgram used here is one of the recommended varieties of Central Agricultural Research Institute (CARI) in Myanmar. The droughtresistance of greengram (var. Kanti) was tested, by being compared with blackgram (var. P-11-30) and soybean (var. Asoaogari) in the experiment 2.

The changing patterns in LWP with SWP in the

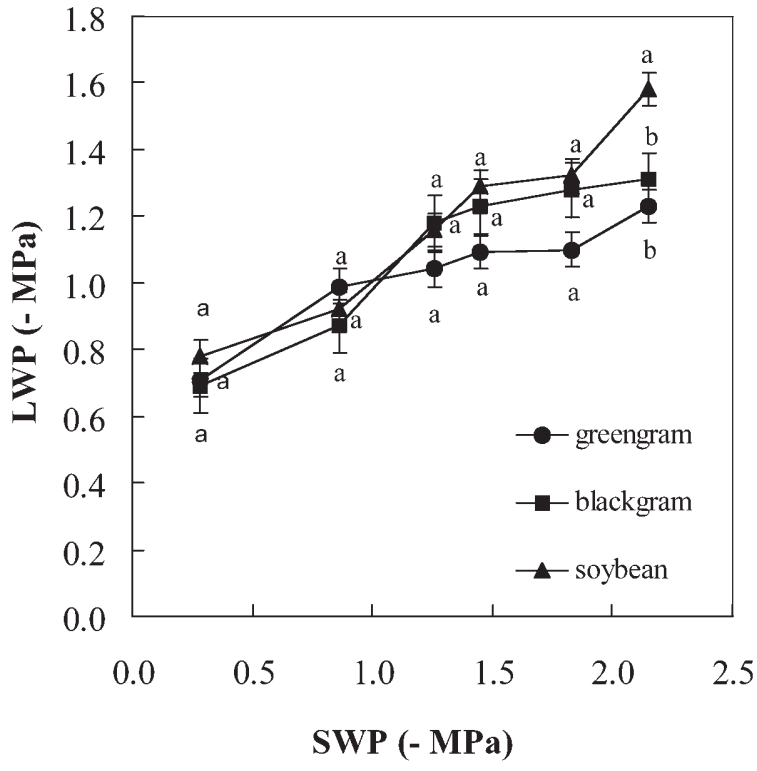

Fig. 2. Changes in LWP with decreasing SWP in leaves of greengram, blackgram and soybean under the drought treatment. Data represent mean $\pm \mathrm{SE}$ of three replications. Mean followed by the same letter represent not significantly different by the Duncan's test at 5\% level.

three species subjected to the drought treatments are shown in Fig. 2. LWP of each species decreased with a reduction in SWP during the drought treatment. There was a significant difference in LWP: $-1.58 \mathrm{MPa}$ in soybean, $-1.31 \mathrm{MPa}$ in blackgram, and $-1.23 \mathrm{MPa}$ in greengram when the soil water status reduced to $-2.15 \mathrm{MPa}$.

This result suggested that greengram and blackgram are less susceptive to soil drought than soybean. The leaf water potential was examined with crops such as soybean and sorghum grown under the drought condition by Blum (1974), and Sammons et al. (1978). They concluded that higher leaf water potentials in certain genotypes indicated an increased droughtresistance. The maintenance of high cell water potentials in species avoids direct metabolic injuries and minimizes the necessity of metabolic adjustments, which are usu-

Table 2. $\mathrm{CO}_{2}$ exchange rate and photosystem II parameter values in three legume species observed under drought and recovery conditions

\begin{tabular}{|c|c|c|c|c|c|c|c|c|c|c|c|c|c|c|c|}
\hline \multirow[t]{2}{*}{ Species } & \multicolumn{2}{|c|}{$\begin{array}{c}\text { CER } \\
\left(\mu \mathrm{mol} \mathrm{m}^{-2} \mathrm{~s}^{-1}\right)\end{array}$} & \multicolumn{3}{|c|}{$\underset{\left(\mathrm{mol} \mathrm{m} \mathrm{m}^{-2} \mathrm{~s}^{-1}\right)}{\mathrm{G}_{\mathrm{s}}}$} & \multicolumn{3}{|c|}{$\mathrm{F}_{\mathrm{v}} / \mathrm{F}_{\mathrm{m}}$} & \multicolumn{3}{|c|}{$\begin{array}{c}\text { ETR } \\
\left(\mu \mathrm{mol} \mathrm{m}^{-2} \mathrm{~s}^{-1}\right)\end{array}$} & \multicolumn{3}{|c|}{$\mathrm{NPQ}$} & \\
\hline & Control & Drought & & Control & Drought & & Control & Drought & & Control & Drought & & Control & Drought & \\
\hline Greengram & $13.24 \mathrm{a}$ & $9.21 \mathrm{a}$ & $(70)$ & $0.152 \mathrm{a}$ & $0.104 \mathrm{a}$ & (69) & $0.82 \mathrm{a}$ & $0.81 \mathrm{a}$ & (99) & $124.34 \mathrm{a}$ & $123.03 \mathrm{a}$ & (99) & $0.46 \mathrm{a}$ & $0.53 \mathrm{~b}$ & (115) \\
\hline Blackgram & $12.08 \mathrm{a}$ & $7.87 \mathrm{a}$ & (65) & $0.138 \mathrm{a}$ & $0.097 \mathrm{a}$ & $(70)$ & $0.83 \mathrm{a}$ & $0.81 \mathrm{a}$ & (97) & $118.52 \mathrm{a}$ & $116.29 \mathrm{a}$ & (98) & $0.33 \mathrm{a}$ & $0.55 \mathrm{~b}$ & (167) \\
\hline \multirow[t]{2}{*}{ Soybean } & $13.58 \mathrm{a}$ & $7.88 \mathrm{a}$ & (58) & $0.140 \mathrm{a}$ & $0.093 \mathrm{a}$ & (66) & $0.83 \mathrm{a}$ & $0.80 \mathrm{a}$ & (96) & $111.98 b$ & $103.22 \mathrm{~b}$ & (92) & $0.38 \mathrm{a}$ & $0.62 \mathrm{a}$ & (163) \\
\hline & Control & Re-water & & Control & Re-water & & Control & Re-water & & Control & Re-water & & Control & Re-water & \\
\hline Greengram & $13.37 \mathrm{a}$ & $12.04 \mathrm{a}$ & (90) & $0.162 \mathrm{a}$ & $0.151 \mathrm{a}$ & (93) & $0.83 \mathrm{a}$ & $0.83 \mathrm{a}$ & (100) & $147.08 \mathrm{a}$ & $152.82 \mathrm{a}$ & (104) & $0.58 \mathrm{a}$ & $0.54 \mathrm{a}$ & (94) \\
\hline Blackgram & $12.70 \mathrm{a}$ & $10.30 \mathrm{a}$ & (81) & $0.140 \mathrm{a}$ & $0.120 \mathrm{a}$ & (86) & $0.83 \mathrm{a}$ & $0.82 \mathrm{a}$ & (99) & $142.94 \mathrm{a}$ & $149.59 \mathrm{a}$ & (105) & $0.55 \mathrm{a}$ & $0.60 \mathrm{a}$ & (109) \\
\hline Soybean & $13.96 \mathrm{a}$ & $10.42 \mathrm{a}$ & (75) & $0.140 \mathrm{a}$ & $0.112 \mathrm{a}$ & (81) & $0.81 \mathrm{a}$ & $0.81 \mathrm{a}$ & (100) & $144.08 \mathrm{a}$ & $139.90 \mathrm{a}$ & (97) & $0.35 \mathrm{a}$ & $0.41 \mathrm{a}$ & (117) \\
\hline
\end{tabular}

Number in the parentheses indicates the percent of the drought to the control value. In a column for each treatment group, mean values followed by the same letters are not significantly different at $5 \%$ level by Duncan's test. See Table 1 for the symbols CER, $\mathrm{G}_{\mathrm{s}}, \mathrm{F}_{\mathrm{v}} / \mathrm{F}_{\mathrm{m}}, \mathrm{ETR}$ and NPQ. 
ally found in drought-tolerant species (Shackel and Hall, 1983). In our experiment, a lenient reduction of LWP in greengram and blackgram during the drought treatment may be regarded as one of the specific traits, contributing to the increment of drought resistance.

Table 2 shows CER, $\mathrm{G}_{\mathrm{s}}, \mathrm{F}_{\mathrm{v}} / \mathrm{F}_{\mathrm{m}}$, ETR and NPQ of theses species determined at the final day of the drought and re-watering treatments. As shown in Fig. 2, the leaf water potentials of greengram, blackgram and soybean, were $-1.23,-1.31$ and $-1.58 \mathrm{MPa}$, respectively. With these reductions in LWP, CER showed 30\% depression in greengram while that of blackgram and soybean were 35 and 42\%, respectively. A leaf water potential of $-1.32 \mathrm{MPa}$ was reported as a level at which sweet potato plants suffered a relativity severe stress (Kubota et al., 1993). Pandey et al. (1984) described on pulse crops that the minimum value of LWP in the driest regimes was -1.26 in greengram, -1.15 in cowpea and $-1.42 \mathrm{MPa}$ in soybean at 60 days after sowing in an upland field. In our experiments, CER in greengram was returned up to $90 \%$ of the control level after rewatering, while that of blackgram and soybean was 81 and $75 \%$, respectively. All the three species used here presented a reduction of $\mathrm{CO}_{2}$ assimilation rates in parallel with a reduction in stomatal conductance under the drought and recovery conditions. As compared with blackgram, a greengram (var. Kanti) showed equal or a little higher resistance in CER to drought. Water loss was more effectively regulated by stomatal closure in Vigna species than in soybean, according to Muchow (1985). However, our conclusion agreed with the report by Yordanov et al. (2003) that the species with a higher drought resistance did not close stomata completely and continued the fixation of carbon under drought stresses, and stomata were reopened rapidly when water deficit was relieved.

$\mathrm{F}_{\mathrm{v}} / \mathrm{F}_{\mathrm{m}}$ ratio and ETR were slightly affected by drought (Table 2). This responding trend was similar to the result shown in Table 1 . By the drought treatment, the value of NPQ in blackgram and soybean increased by 67 and 63\%, respectively only a slight increase was found in greengram (15\%). Thus, it is predicted that photochemical activity in the three species was not affected by the drought treatment imposed here. However, non-photochemical energy dissipation mechanisms were more greatly functioned in blackgram and soybean in the drought stress, which means that the photosynthesis of a greengram (var. Kanti) was less stressed by drought compared with the other two species used here.

There were many comparative studies on the physiological response of greengram, blackgram, cowpea and soybean in different soilwater regimes (Lawn 1982 and 1983). This performance provides that Vigna species (greengram, blackgram and cowpea) have a more advantageous system to survive under drought conditions than soybean. On the other hand, Senthong and Pandey (1989) described that greengram species are more sensitive to soil moisture deficits than other pulses such as cowpea, soybean, peanut and pigeonpea.
However, in our study, of the three pulse species, the higher resistance in photosynthesis to drought was observed in greengram than blackgram and soybean. It may be considered that the greengram variety (Kanti) used here is included in the genotype group with an especially high droughtresistance. The introduction of vars. Kanti is expected to improve greengram production in dry regions of Myanmar. A large varietal difference among greengram genotypes may suggest a high possibility of genetic improvement of drought resistance of this species.

\section{ACKNOWLEDGEMENTS}

The authors acknowledge to the Japanese Ministry of Education, Culture, Sports, Science and Technology for the financial support.

\section{REFERENCES}

Anyia, A. O. and H. Herzog 2004 Genotypic variability in drought performance and recovery in cowpea under controlled environment. J. Agron. Crop Sci., 190: 151-159

Bilger, W. and O. B. Björkman 1990 Role of xanthophylls cycle in photo-protection elucidated by measurements of light induced absorbance changes, fluorescence and photosynthesis in leaves of Hedera canariensis. Photosynth. Res., 25: $173-185$

Blum, A. 1974 Genotypic response in sorghum to drought stress. 1. Response to soil moisture stress. Crop Sci., 14 361-364

Chaves, M. M. 1991 Effects of water deficits on carbon assimilation. J. Exp. Bot., 42: 1-16

Cornic, G. 2000 Drought stress inhibits photosynthesis by decreasing stomata aperture-not by affecting ATP synthesis. Trends Plant Sci. 5: 187-188

Earl, H. J. 2002 Stomatal and non-stomatal restrictions to carbon assimilation in soybean (Glycine max) lines differing in water use efficiency. Environ. Exp. Bot., 48: 237-236

Genty, B., J. M. Briantais and J. B. Viera da Silva 1987 Effects of drought on primary photosynthetic processes of cotton leaves. Plant Physio., 143: 642-650

Genty, B., J. M. Briantais and N. R. Baker 1989 The relationship between the quantum yield of photosynthetic electron transport and quenching of chlorophyll fluorescence. Biochem. Biophys. Acta., 990: 87-92

Kage, H., M. Kochler, H. Stützel 2004 Root growth and dry matter partitioning of cauliflower under drought stress conditions: measurement and simulation. Eur. J. Agron., 20: 379-394

Klepper, B., R. W. Rickman 1990 Modeling crop root growth and function. Adv. Agron., 44: 113-132

Krall, J. P. and G. E. Edwards 1992 Relationship between photosystem II activity and $\mathrm{CO}_{2}$ fixation in leaves. Physiol. Plant., 86: 180-187

Kubota, F. Yoshimura, Y. and W. Agata 1993 Stomatal movement and $\mathrm{CO}_{2}$ exchange rate of sweet potato plant (Ipomoea batatas Lam.) in relation to water environments. A comparison between native and improved varieties. J. Fac. Agri., Kyushu Univ., 38: 97-110

Lawn, R. C. 1982 Response of four grain legumes to water stress in south-eastern Queensland. I. Physiological response mechanisms. Aust. J. Agri. Res., 33: 481-496

Lawn, R. C. 1983 Response of four grain legumes to water stress in south-eastern Queensland. IV. Interaction with sowing arrangement. Aust. J. Agri. Res., 34: 661-669

Long, S. P., J-E. Hallgren 1985 Measurement of $\mathrm{CO}_{2}$ assimilation by plants in the field and the laboratory. In "techniques 
in bioproductively and photosynthesis", ed. by J. Coombs et al., Pergamon Press, Oxford, pp. 62-94

Maxwell, K., G. N. Jonhson 2000 Chlorophyll fluorescence-a practical guide. J. Exp. Bot. 51: 659-668

Miyashita, K., S. Tanakamura, T. Maitani, K. Kimura 2005 Recovery response of photosynthesis, transpiration and stomatal conductance in Kidney bean following drought stress. Environ. Exp. Bot., 53: 205-214

Muchow, R. C. 1985 Phonology, seed yield and water used of grain legumes grown under different soil regimes in a semiarid tropical environment. Field Crops Res., 11: 81-97

Pandey, R. K., W. A. T. Herrera, and J. W. Pandleton 1984 Drought response of grain legumes under irrigation gradient: II. Plant water status and canopy temperature. Agron. J., 76: $553-557$

Sammons, D. J., D. B. Peters, and T. Hymowitz 1978 Screening soybeans for drought resistance. I. Growth chamber procedure. Crop Sci., 18: 1050-1055

Schultz, H. R. 1996 Leaf absorptance of visible radiation in
Vitis vinifera L.: estimates of age and shade effects with a simple field method. Sci. Hort. 66: 93-102

Senthong, C., and R. K. Pandey 1989 Response of five food legumes to an irrigated gradient imposed during reproductive growth. Agron. J., 81: 680-686.

Shackel, K. A., A. E. Hall 1983 Comparison of water relations and osmotic adjustment in sorghum and cowpea under field conditions. Aust. J. Plant Physiol. 10: 423-435

Souza, R. P., E. C. Machado, J. A. B. Silva, A. M. M. Lagoa and J. A. G. Silveira 2004 Photosynthetic gas exchange, chlorophyl fluorescence and some associated metabolic changes in cowpea (Vigna unguiculata) during water stress and recovery. Environ. Experi. Bot., 51: 45-56

van Kooten, O. and J. F. H. Snel 1990 The use of chlorophyll fluorescence nomenclature in plant stress physiology. Photosynth. Res., 25: 147-150

Yordanov, I., Tsonev, T. and V. Velikova 2003 Plant response to drought and stress tolerance. BULG. J. Plant Physiol., Special Issue: $187-20$ 
